\title{
Influence of Globalisation on Project Delivery and Organisational Performance
}

\author{
Telema Osima Isokariari ${ }^{1 *}$, Cross Ogohi Daniel ${ }^{2}$ \\ ${ }^{1}$ Department of Business Administration, \\ Nile University of Nigeria, \\ Abuja,Nigeria \\ ${ }^{2}$ Department of Business Administration, \\ Nile University of Nigeria, \\ Abuja, Nigeria \\ *Corresponding author's email: isotelema [AT] gmail.com
}

\begin{abstract}
The study is an empirical analysis of the influence of globalization on project delivery and organisational performance. This is borne out of the problem that globalization is an ambivalent concept and process with its strengths, weaknesses, opportunities and threats (SWOT) or with costs, benefits and burdens. The objectives of the study are to examine the significant influence of economic liberation on project delivery and organisational performance; to examine the significant influence of technological innovation on organizational performance and project delivery. Being an empirical development research, the survey research design involving the collection, collation and use of primary and secondary data from a representative sample population of 150 (one hundred and fifty) respondents was used. Descriptive and inferential statistics with the aid of the Statistical Package for Social Sciences (SPSS) were used in data presentation, analysis and test of hypotheses in which all null hypotheses were rejected in favour of the alternate hypotheses which were accepted. Based on the findings, the following recommendations were made; in the opening of economic borders and removal of trade barriers, nation's economic flows should be increased to enable firm's increase their productivity and efficiency and Company management should try to devise strategies to fulfill consumer perspective to survive in competitive market.
\end{abstract}

Keywords - Globalization; Project Delivery; Technological Innovation and Organisational Perfor[mance

\section{INTRODUCTION}

Organizations are evaluated to know how well they perform by being compared to other organizations in the global arena because the world is now a small village due to globalization. Organizations are successful and profitable because of the emergence of globalization. Removing the impediments existing in corporate deals and financial speculation, business can have more chances of developing. Also, the introduction of the changes from time to time of this era of technological development and innovation, investors trying to accomplish their business at any environment are spurred up by other firms that show superior opportunities for businesses. In this way organizations performance is vital to spurring up the general business public to come to it and investors must enhance company achievements through new initiatives and methods to follow up current trend in its operations and business in its life cycle (Ejiogu, et al, 2017).

Since the 1980s, there has been a dramatic but enormous change in the world. This change is evident in the increasing rate and the continuous shrinking of world societies and economies into an integrated and interconnected whole. The intensification is so significant that almost all have acknowledged the emergence of a new world society or global community (Dada, 2004). This change is generally referred to as globalization. Globalization is supplanting the primacy of the nation state with trans-national, and or multinational companies and organizations. With increasing globalization, there have been enormous and far reaching changes in global organizations. These changes are the result of fierce international competitive pressure faced by enterprises operating in the global market place. These changes have presented a situation whereby there are gainers and losers in the global market place. This implies that the performance of organizations and the handling capability of project by a company are impliedly linked with this contemporary global order (Wokoma \& Iheriohanma 2010).

Human Factor is the main success factor in project management. Human Factor is difficult to align with "classical" project management methods like time, cost or scope management, where the achievements are measurable, methods, techniques and best practices for all possible cases are available. In job advertisements, which call for project managers, 
you will find terms like "shall be communicative" or "team oriented" and you may bet - there is weak or no interference with real tasks the candidate later has to do.

The rapid rise of a global economy in last 20 years has ensured that geographical boundaries, cultural \& linguistic differences are not important factors in setting up business establishments in alien countries. Impact of globalization has also led to generalized regulations and common standards in conducting business transactions worldwide. Quality assessment standards like ISO, BS and other regulatory affairs have ensured that policies and framework are nor distinct and neither exclusive to local laws. Thus, the internationalization of markets has increased competitive pressures on business enterprises which lead them to engage in projects that are critical to their performance (Raymond \& Bergeron, 2007). It is important that these projects are planned, staffed, organized, monitored, controlled and evaluated within a schedule time frame to ensure success and desired outcome (Liberatore \& Pollack, 2003).

\section{STATEMENT OF PROBLEM}

Working in the world's market builds increasing risk and the vulnerability experienced by firms in this way influences their outcome. Companies are confronted with expanding challenges in arranging and deciding (Chimerine, 1997). Request has turned difficult to project since developing companies now take part in the world's market, gauging interest and contender's reactions has turned out to be challenging. Companies are confronted with less evaluating adaptability because of increased rivalry and purchaser's resistance, which has prompted low profit. The problem of this study is derived from the fact that the advent and genesis of the 21st century brought unprecedented and largely unanticipated change in the global outlook, with the emergence of global economic systems. This change is manifested in the alteration of the economic structures, organizations, means of production, project handling and distribution of goods and services (Ayantayo, 2004).

Porous international boundaries and trans-border flows of capital caused by globalization have precipitated a relentless proliferation of multicultural projects (Ghoshal, 1987). This has caused a major change in the way project is implemented in the present day. The link that exists in project delivery and the performance of the organization implementing the project has made the topic of globalization and its effect on global economy a keen interest to study. To its proponents, globalization is good because it reflects progress, development, advancement and growth. This is because, through free trade and interactions among nations, globalization pushes economies and organizations towards higher levels of performance and efficiency in project delivery (Iheriohanma, 2008).

To a significant other, globalization is a dangerous development because it tends to erode the hitherto prevalent practices and is accompanied by some social and economic crises such as collapse of producer prices, low organizational performance, increase in unemployment and poverty especially in Africa where there are no developed social and economic structures necessary for participation in globalization (Iheriohanma, 2008). To this end, this study seeks to examine the influence of globalization on project delivery and organizational performance.

\section{OBJECTIVES OF THE STUDY}

The objective of this study was to investigate the influence of globalization on project delivery and organizational performance, with the sub-variables used to measure globalization to be economic liberalization and technological innovation. Specifically, the study focused on the following objectives.

a. To examine the significant influence of economic liberation on project delivery and organisational performance.

b. To examine the significant influence of technological innovation on organizational performance and project delivery

\section{RESEARCH HYPOTHESES}

The study will be guided under the following hypotheses

There is no significant influence of economic liberation on project delivery and organizational performance.

There is no significant influence of technological innovation on project delivery and organizational performance.

\section{LITERATURE REVIEW}

\subsection{Concept of Globalization}

Globalization is the process by which communities which were formally distant and unrelated are now continually brought together overtime to make a multifarious whole with an array of many flourishing subcultures.

According to Iheriohanma (2008), globalization is both a phenomenon and a process that sees the world as being linked by economic interdependence, political and socio-cultural relations through the bridging of the factors of geographic distance in the establishment and sustenance of free border crossing. Globalization is a phenomenon whereby distinct and separate national markets are becoming one huge global market place, with resulting internationalization of production and selling to the world as one market (Adei, 2004). 
Armstrong (2009) sees globalization as the economic integration and interdependence of national economies across the globe, through a rapid increase in cross-border movement of goods, services, technology, financial and human resources, facilitated by economic liberalization and information technology. This integration, interdependence and movement of resources across borders are made possible by the opening up of national economies through liberalization which has resulted in the entrance and expansion of multinational corporations into foreign localities and nations. The new information and communication technology as well as advances in other technologies such as transportation, has significantly been a major pusher of globalization. Through technology, global transactions and activities are carried out within fragments of time and remotely. Advocates of globalization said that economies seriously occupied with globalization process are probably going to encounter higher economic development and more prominence in democratic ruling system, and peaceful environment.

\subsection{Organizational Performance}

Organizational performance has setbacks in getting a generally accepted definition, as well as a conceptual problem. Although the idea of organizational performance is extremely basic in the academic research; in the 1950s, organizational performance was described as the degree by which firms see a social system to achieve their targets. The idea of an organization that achieves its performance objectives in spite of the constraints faced due to scarce resources in their disposal are supported by theorists of firm theory (Lushaus \& Adrien, 1998).

Performance according to Lebans \& Euske (2006) is a financial and non-financial pointer that tells the extent of achievement of results. Recently, organizations have tried to use the balance scorecard method to track and measure performance of shareholders return, customer service social responsibility (e.g. corporate citizenship, community outreach) and employee stewardship to manage firm performance.

\subsection{Project Delivery}

Globalization has impacted project management profoundly, and has only reinforced the trend toward adoption of the project mode of work organization. Globalization in project management means among other matters more projects executed in the multi-cultural environment. With the advent of globalization, project management is no longer a local issue, but an international affair that is risky in nature.

Changes in the global environment are presenting organizations with both opportunities and challenges. However, a review of the results of project monitoring and evaluation on World Bank projects indicates that many of the key problems of implementation lie in the general environment of the project, and are not under the direct control of the project manager. However, as the world is progressing towards one global economy, it is important to rely and carve a strategic plan on the perceptions and interpretations of global market economy and respond with a temporal focus i.e. with what urgency do the short and long-term horizons are considered and how stakeholders view the effect of short term actions on conditions for long term developments (Andersson \& Mattsson, 2010). Evaluating further, it has to be considered that external factors like change of governance, resource issues related to procurement and labour laws and economic growth metrics through inflation and currency depreciation can impact the alignment in a major way (Dille \& Soderlund, 2011).

\subsection{Economic Liberalization}

The primary purpose of recent globalization process in the world today is economic liberalization, which is welcomed everywhere by all nations and organizations in the world. It is basically, the process toward accomplishing unhindered economic activities. It tries to eliminate all hindrances to business, manufacturing and investment, with emphasis on free trading and capitalism, and separation of the economy from the state.

It is the procedure whereby international economies allow for privatization and deregulation of their economies for increased profit and more cooperation among private organizations. It encourages government to withdraw from participating directly in business activities, and engaging business regulators to control and partner with investors by providing a level playing ground for organizations to flourish.

With the freedom of trade in international boundaries, companies are relied upon to increase their productivity by getting important economic movement of money, innovations in technology and human capital. Knowing that if economic activities increase it empowers organizations to raise supply of profitable capital. They additionally state that with liberalization, most governments' policies reduced restrictions to control trade and capital and services transfer which allows the forces of market to play out.

Capital flow that is unhindered is a necessary objective for economic liberalization. This is done by removing protectionist strategies, like custom duties, trade laws and other international trade barriers. One primary impacts of this increased capital flow into nations is that it makes it less expensive for organizations to get capital from investors. Low capital cost enables organizations to attempt productive businesses that they might not have engaged in considering the high cost of capital involved, prompting higher development growth. 


\subsection{Technological Innovation}

The world is presently experiencing extraordinary innovative and technological circles changes. The rising change is as a result of technological inflows, particularly computer innovation; Computer innovation prompted the progression of innovational communication that thusly has improved the level of data dissemination and transactions of business. Economies have faced real challenges since the advent of Globalization and information technology, particularly the financial framework had reduced the world to a small common town, and also by giving huge information through an extensive variety of interconnectivity. The computers linkages have offered increase to the growth of internet, being the biggest system supply of data.

Information technology similarly has brought about an overwhelming opportunity to tap on mass production, giving way for massive progress and presenting relative advantage for those who have taken advantage of it. Advancing profitability and market internationally is essential for globalization activities (Kwanashie, 1999). Technological advancements have basically played a major part in forming trans-world social spaces (Adei, 2004). Technology advancement, information and communications technology are the foundation of globalization. It enhances transportation and introduced containerization in land and sea-based transporting which reduce requirement for handling and travelling reasonably.

Company cannot be a major actor without the use of communication technology. Information and technology assume a major part for modern companies. They are relied upon to drive firms to perform better. As indicated by Adei (2004), usually it is thought that every development takes place in the western world. The know-how comes into underdeveloped nations because of globalization. Without it, new discoveries and drugs would remain in the nations that had that innovation and nobody else would profit. The spread can likewise be extended to incorporate information economically and politically, which too has reached everywhere.

\section{METHODOLOGY}

The Hypotheses will be tested using linear regression as well as Pearson product moment correlation. The R-value generated points to the type and extent of relationship between the variables while the significance of the relationship will be determined by comparing the generated p-value to 0.05 level of significance.

\section{TEST OF HYPOTHESES}

This research shall here apply the technique described in the methodology to test for the validity of the hypotheses.

\section{Test of Hypothesis One}

$\mathrm{H}_{\mathrm{O}}$ : There is no significant influence of economic liberalization on project delivery and organizational performance

$\mathrm{H}_{1}$ : There is no significant influence of economic liberalization on project delivery and organizational performance

Table 1. Descriptive Statistics

\begin{tabular}{|l|l|l|l|}
\hline & Mean & Std. Deviation & $\mathrm{N}$ \\
\hline $\begin{array}{l}\text { Economic liberation on } \\
\text { Project delivery }\end{array}$ & 1.7766 & .51738 & 90 \\
ional performance & 3.4727 & .85386 & 90 \\
\hline
\end{tabular}


Table 2: Correlations

\begin{tabular}{|c|c|c|c|}
\hline & & $\begin{array}{l}\text { Economic } \\
\text { liberation } \\
\text { Project } \\
\text { delivery }\end{array}$ & organizational performance \\
\hline Pearson Correlation & $\begin{array}{l}\text { Economic liberation on } \\
\text { Project delivery } \\
\text { organizational performance }\end{array}$ & $\begin{array}{l}1.000 \\
.682 \\
\end{array}$ & $\begin{array}{l}.682 \\
1.000 \\
\end{array}$ \\
\hline Sig. (1-tailed) & $\begin{array}{l}\text { Economic liberation on } \\
\text { Project delivery } \\
\text { organizational performance }\end{array}$ & .000 & .000 \\
\hline $\mathrm{N}$ & $\begin{array}{l}\text { Project delivery } \\
\text { organizational performance }\end{array}$ & $\begin{array}{l}90 \\
90\end{array}$ & 90 \\
\hline
\end{tabular}

Table 3: Model Summary

\begin{tabular}{|l|l|l|l|l|l|l|}
\hline Model & $\mathrm{R}$ & R Square & $\begin{array}{l}\text { Adjusted } \\
\text { Square }\end{array}$ & $\begin{array}{l}\text { R } \\
\text { Std. Error of the } \\
\text { Estimate }\end{array}$ & Durbin-Watson \\
\hline 1 & $.682^{\mathrm{a}}$ & .465 & .463 & .37899 & .064 \\
\hline
\end{tabular}

a. Predictors: (Constant), project delivery

b. Dependent Variable: organizational performance

Table 4: ANOVA ${ }^{b}$

\begin{tabular}{|ll|l|l|l|l|l|}
\hline Model & & Sum of Squares & Df & Mean Square & F &. \\
\hline 1 & Regression & 47.778 & & 47.778 & 332.632 & $.000^{\mathrm{a}}$ \\
& Residual & 55.012 & & .144 & & \\
& Total & 102.790 & & & & \\
\hline
\end{tabular}

a. Predictors: (Constant), economic liberation project delivery

b. Dependent Variable: organizational performance

Table 5: Coefficients

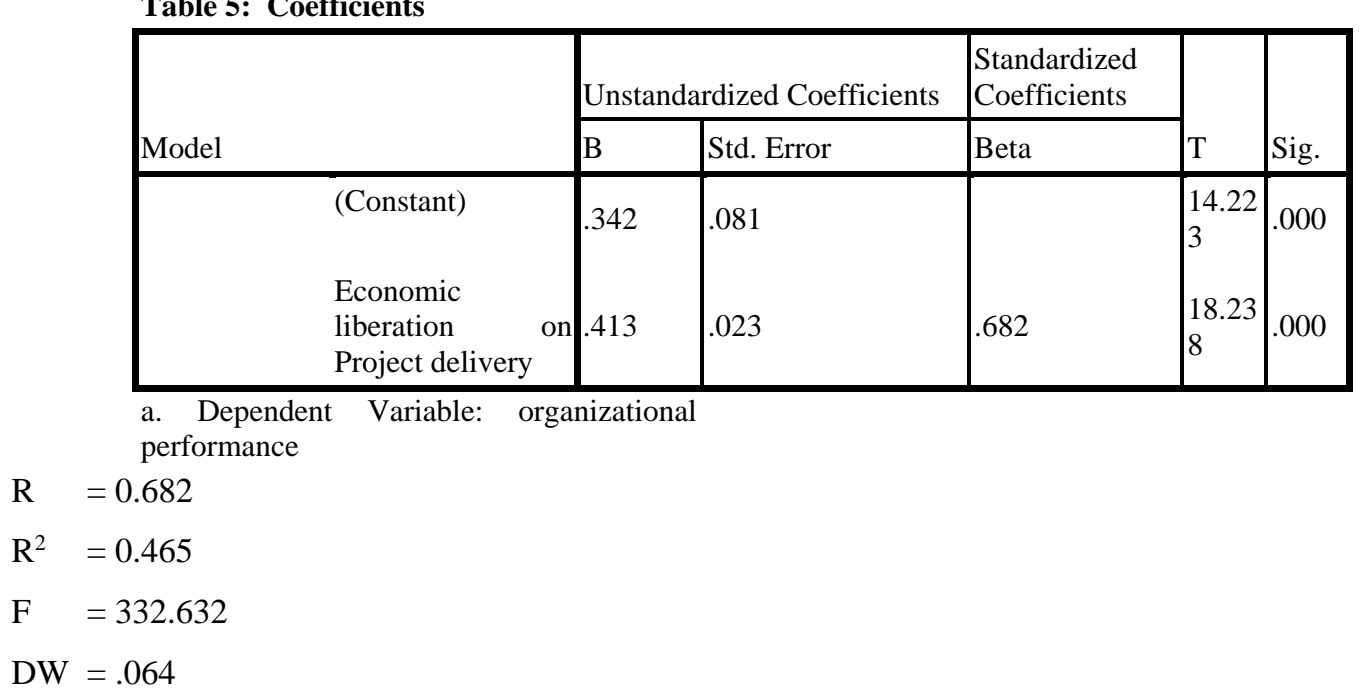




\section{Interpretation:}

The regression sum of squares (47.778) is less than the residual sum of squares (55.012), which designates that more of the variation in the dependent variable is not explained by the model. The significance value of the $\mathrm{F}$ statistics $(0.000)$ is less than 0.05 , which means that the variation explained by the model is not due to chance.

$\mathrm{R}$, the correlation coefficient which has a value of 0.682 , indicates that there is a significant influence of economic liberalization on project delivery and organizational performance. R square, the coefficient of determination, shows that $46.5 \%$ of the variation in organizational performance is explained by the model.

With the linear regression model, the error of estimate is high, with a value of about 0.37899 . The Durbin Watson statistics of .064, which is not tends to 2 indicates there no is autocorrelation. Project delivery coefficient of 0.682 indicates a positive significant influence of economic liberalization on project delivery and organizational performance, which is statistically significant (with $t=14.223$ ). Therefore, the null hypothesis should be rejected and the alternate hypothesis accordingly accepted.

\section{Test of Hypothesis Two}

$\mathrm{H}_{\mathrm{O}}$ : There is no significant influence of technological innovation on project delivery and organizational performance.

$\mathrm{H}_{1}$ : There is a significant influence of technological innovation on project delivery and organizational performance.

Table 6: Descriptive Statistics

\begin{tabular}{|l|l|l|l|}
\hline & Mean & Std. Deviation & $\mathrm{N}$ \\
\hline $\begin{array}{l}\text { Technological innovation } \\
\text { on project delivery } \\
\begin{array}{l}\text { Organisational } \\
\text { performance. }\end{array}\end{array}$ & 2.8253 & 1.27682 & 90 \\
\hline
\end{tabular}

Source: SPSS version 20.00

Table 7: Correlations

\begin{tabular}{|c|c|c|c|}
\hline & & $\begin{array}{l}\text { Technological } \\
\text { innovation on project } \\
\text { delivery }\end{array}$ & $\begin{array}{l}\text { Organisati } \\
\text { onal } \\
\text { performan } \\
\text { ce. }\end{array}$ \\
\hline \multirow{3}{*}{$\begin{array}{l}\text { Technological } \\
\text { innovation on } \\
\text { project delivery }\end{array}$} & $\begin{array}{l}\text { Pearson } \\
\text { Correlation }\end{array}$ & 1 & $.716(* *)$ \\
\hline & Sig. (2-tailed) & & .000 \\
\hline & $\mathrm{N}$ & 90 & 90 \\
\hline \multirow[t]{3}{*}{$\begin{array}{l}\text { Organisational } \\
\text { performance. }\end{array}$} & $\begin{array}{l}\text { Pearson } \\
\text { Correlation }\end{array}$ & $.716(* *)$ & 1 \\
\hline & Sig. (2-tailed) & .000 & \\
\hline & $\mathrm{N}$ & 90 & 90 \\
\hline
\end{tabular}

\section{** Correlation is significant at the 0.01 level (2-tailed).}

\section{Source: SPSS version 20.00}

Table (6) shows the descriptive statistics with a mean response of 2.8253 and std. deviation of 1.27682 for levels of workers participation and a mean response of 3.1613 and std. deviation of 1.37593 for decision making of the organizations and number of respondents (90). By careful observation of standard deviation values, there is not much difference in terms of the standard deviation scores. This implies that there is about the same variability of data points between the dependent and independent variables.

Table (7) is the Pearson correlation coefficient for levels of technological innovation on project delivery of the organizations. The correlation coefficient shows 0.716 . This value indicates that correlation is significant at 0.05 level (2tailed) and implies that there is a significant influence between technological innovation on project delivery and organisational performance $(r=.716)$. The computed correlations coefficient is greater than the table value of $r=.195$ with 383 degrees of freedom $(\mathrm{df} .=\mathrm{n}-2)$ at alpha level for a two-tailed test $(\mathrm{r}=.716, \mathrm{p}<.05)$. However, since the 
computed $r=.716$, is greater than the table value of .195 we reject the null hypothesis and conclude that There is a significant influence of technological innovation on project delivery and organizational performance.

$(\mathrm{r}=.716, \mathrm{P}<.05)$.

\subsection{Discussion of Results}

Hypothesis one was tested using simple linear regression to find out how economic liberation on project delivery has a significant influence on organisational performance. With a computed result $(\mathrm{r}=0.682 ; \mathrm{F}=332.632 ; \mathrm{t}=14.223 ; \mathrm{p}<$ 0.05).The null hypothesis was rejected and alternate hypothesis was accepted resulting in the conclusion that There is a significant influence of economic liberalization on project delivery and organizational performance

Hypothesis two was tested with Pearson's product moment correlation in order to ascertain the level of technological innovation on project delivery has on organisational performance, with a computed result $(r=0.716 ; p<0.05)$, the null hypothesis was rejected and the alternate hypothesis was accepted resulting in the conclusion that There is a significant influence of technological innovation on project delivery and organizational performance.

\section{CONCLUSION}

From the findings of this study, it can be concluded that globalization has a significant influence on project delivery and organizational performance. The following conclusions were arrived at

i. Economic liberalization has a significant influence on project delivery and organizational performance.

ii. Technological innovation has a significant influence on project delivery and organizational performance.

\section{RECOMMENDATIONS}

Based on the findings, the following recommendations were made:

i. In the opening of economic borders and removal of trade barriers, nation's economic flows should be increased to enable firms increase their productivity and efficiency.

ii. Company management should try to devise strategies to fulfill consumer perspective to survive in competitive market.

iii. Nations with abundance of resources should key in and use the availability of the adequate manufacturing techniques advantageously over other nations in the dynamic global atmosphere.

iv. Firms should have skill, knowledge and be committed to quality service delivery to satisfy customers.

v. Quality control and its technological implications are very relevant to ensuring desired standard quality.

\section{REFERENCES}

[1] Adei, S. (2004). Impact of globalization on management: The African perspective. management in Nigeria. Journal of Nigerian Institute of Management, 39/40(1/2), 3-15.

[2] Andersson, P. \& Mattsson, L. (2010). Temporality of resource adjustments in business networks during severe economic recession, Industrial Marketing Management, 39 (6), 917 - 924.

[3] Armstrong, M. (2009). Armstrong's Handbook of Human Resource Management Practice. London:Kogan Page.

[4] Ayantayo, J. K. (2004). Globalization: a new ethnocentric culture with impact on African social values. International Review of Politics and Development, 2(2), 54-64.

[5] Chimerine, L. (1997). The new economic realities in business. McKinsey Quarterly, 86(1), 12-17.

[6] Dada, S. O. (2004). Globalization and the future of sovereignty. International Review of Politics and Development, 2(2), 24-39.

[7] Dille, T. \& Söderlund, J. (2011). Managing inter-institutional projects: The significance of isochronism, timing norms and temllporal misfits. International Journal of Project Management, 29 (4), 480-490.

[8] Ejiogu, V. C., Onuoha, B. C. \& Nwede, I. G. N. (2017). Globalization and performance of manufacturing firms in Port Harcourt. International Journal of Advanced Academic Research, 3(11), 2.

[9] Heffernan, M. M. \& Flood, C. P. (2000). An exploration of the relationship between managerial competitive organizational characteristic and performance in an organization. Journal of European industrial training university press, 128-136. 
[10] Iheriohanma, E. B. J. (2008). The challenges of globalization and poverty in the third world: A sociological discourse of nigeria's situation. In J. O. Onwuka, (ed) The Third World in Sociological Perspective. Okigwe: FERP-FASMEN, 241255.

[11] Lebans, M. \& Euske, K. (2006). A conceptual and operational delineation of performance. Business performance Measurement. Cambridge University Press.

[12] Liberatore, M. J. \& Pollack-Johnson, B. (2003). Factors influencing the usage and selection of project management software. IEEE Transactions on Engineering Management. 50 (2), 164-174.

[13] Lushaus, C. \& Adrien, M. H. (1998). Organizational assessment. A review of experience universalia, 31

[14] Raymond, L. \& Bergeron, F. (2008). Project management information systems: An empirical study of their impact on project managers and project success. International Journal of Project Management, 26 (1), 213 - 220, doi:10.1016. .

[15] Sharma, B. \& Gadenne, D. (2002). An inter-industry comparison of quality management practices and performance. Managing Service Quality, 12(6).

[16] Upadhaya, B., Munir, R. \& Blount, Y. (2014). Association between performance Measurement systems and Organisational Effectiveness. International journal of operations \& Production management, 34(7), 2.

[17] Wokoma, C. U. \& Iheriohanma, E. B. J. (2010). Interaction between globalization and organizational performance in the third world: Nigeria in focus. Studies of sociology of science, 1(2), 72-80. 